УАK 341.3

ББК 67.408 .16

DOI 10.22394/1682-2358-2020-1-57-63

G.V. Vershitskaya, Candidate of Sciences (Law), Docent of the Administrative and Criminal Law Department, Povolzhsky Institute of Management named after P.A. Stolypin, Branch of the Russian Presidential Academy of National Economy and Public Administration

\section{SOME FORENSIC ASPECTS OF INVESTIGATING EXTREMIST CRIMES}

Criminalistic aspects of special knowledge application in investigation of extremist crimes in the sphere of telecommunications and computer information are considered. Proposals are formulated to improve forensic methods of extremist crimes investigation, as well as psychological, linguistic and religious expertise results quality.

Key words and word-combinations: extremist crimes, psychological and linguistic expertise, religious-oriented expertise.
Г.В. Вериичкая, кандидат юориичеких наук, доцент кафедрь административного и уголовного права Поволжского института управления имени П.А. Стольгпина - филиала Российской академии народного хозяйства и государственной службь при Президенте РФ (email:vershickaya@yandex.ru)

\section{HEKOTOРЫЕ}

КРИМИНААИСТИЧЕСКИЕ

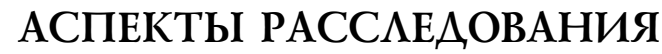
ПРЕСТУПАЕНИЙ ЭКСТРЕМИСТСКОЙ

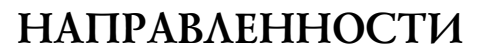

\begin{abstract}
Аннотация. Рассматриваются криминалистические аспекты применения специальных знаний при расследовании преступлений экстремистской направленности в сфере телекоммуникаций и компьютерной информации. Формулируются предложения по совершенствованию криминалистической методики расследования преступлений экстремистской направленности и по повышению качества результатов психолого-лингвистической и религиоведческой экспертизы.
\end{abstract}

Ключевые слова и словосочетания: преступления экстремистской направленности, психолого-лингвистическая экспертиза, религиоведческая экспертиза.

Э кстремизм представцяет собой Аеятельность организованных структурированных групп против основ конституционного строя и безопасности государства, выражкается в отрицании существующих 
общественных норм и правим в государстве и является острой соџиально значимой проблемой последних десятилетий в Российской Федераџии.

Причины распространения экстремистских идей в обществе ничем не отличаются от причин распространения организованной преступности в цемом. Но организованные экстремистские группировки формируются по так называемому «сетевому» принџипу, что принџипиально отличается от траАиционных иерархических приемов построения организованных преступных групп. Организации, построенные по «сетевому принципу», состоят из отдельных ячеек, каждая из них является самостоятельной единицей и может действовать как автономно, так и участвовать в проведении групповых акций по мотивам идеологической, наџиональной, религиозной ненависти и вражаы.

Современные информационные возможности подняли экстремистскую деятельность на новый уровень, расширив и облегчив возможность распространения экстремистских материалов. Аоступность Интернета, анонимность пользователя, отсутствие цензуры и контроля, небольшие финансовые затраты, наличие огромной аудитории во всем мире, на сознание которой можно оказывать влияние, привлекают участников экстремистских группировок. Аидеры экстремистских движений в первую очередь пытаются воздействовать на молодое поколение, которое активно пользуется интернет-сервисами и мегко попадает в сферу их влияния.

Правовую основу противодействия экстремистской деятельности в современной России составцяют Конституция РФ, Уголовный кодекс РФ, Угомовно-проџессуальный кодекс РФ, Федеральный закон от 25 июля 2002 г. № 114-Ф3 (в реА. от 23 ноября 2015 г.) «О противодействии экстремистской деятельности», приказ Следственного комитета РФ от 12 июля 2011 г. № 109 «О мерах по противодействию экстремистской деятельности».

Председатель Следственного комитета Российской Федерации А.И. Бастрыкин во исполнение приказа Следственного комитета РФ № 109 в качестве приоритетного направления деятельности следственных органов указал противодействие экстремизму [1]. САедственный комитет Российской Федерации проводит расследование преступлений экстремистской направленности, преАусмотренных ст. 141, 136, 205, 205.1, 205.2, 282, 282.1, 282.2, 318 Уголовного кодекса РФ [2] .

При расследовании преступлений, связанных с экстремизмом, возникает ряд криминалистических проблем по собиранию доказательств. Аیя решения этих проблем необходимо учитывать все структурные элементы криминалистической характеристики указанных преступлений, имеющих методическое значение. Наиболее значимым элементом с точки зрения методики расследования данных преступлений, по нашему мнению, явмяются особенности Аичности преступника.

С целью изобличения миџ, совершивших преступления экстремистской направленности, в 2001 г. в МВА России было образовано специализированное подразделение - Управление «К» (Бюро специальных технических мероприятий МВА России), а в 2008 г. - ГАавное управление по борьбе с экстре- 
мизмом и терроризмом МВА России. Основными направлениями служебной деятельности данных подраздемений является противодействие преступлениям в сфере компьютерной информации и международным преступмениям в сфере информаџионных технологий, а также борьба с экстремизмом и терроризмом.

КАючевым вопросом в ходе расследования преступцений в сфере телекоммуникаций и компьютерной информации является установление мидера экстремистской группы. Информация о кичности преступника, полученная на первоначальном этапе расследования, дает возможность выдвинуть следственные версии о мотиве, способе и Аругих обстоятельствах совершения преступления, а также спланировать проведение проџессуальных действий и оперативно-розыскных мероприятий, направленных на получение и закрепление доказательств о причастности конкретного миџа к расследуемому преступмению.

Аля определения мидера экстремистской группировки или установления миџ, распространяющих информаџию экстремистского содержания в Интернете, необходимо, на наш взгяяА, активно использовать методологию, теорию и практику стремительно развиваюшейся в настоящее время отрасли психомогии, которую известный психолог А.Е. Войскунский назвал киберпсихологией, или психологией Интернета [3] . Например, спеџиалист-киберпсихолог в рамках своей компетенции может оказать помощь в организаџии и реализаџии психологического сопровождения действий по внедрению сотрудника правоохранительных органов посредством соџиальных сетей в экстремистскую группировку, чтобы через посреАников или приближенных киџ получить Аоступ к мидеру организаџии.

В ходе расследования преступлений экстремистской направленности обязательно производство ряда судебных экспертиз с целью установления признаков экстремистских проявлений, получения и закрепления доказа-

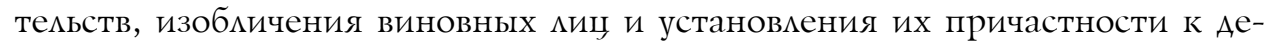
ятельности экстремистских сообществ и организаций. Так, использование спещиальных знаний необходимо по делам о возбуждении ненависти мибо вражды, об унижении человеческого достоинства (ст. 282 УК РФ), по Аемам о публичных призывах к осушествлению экстремистской деятельности (ст. 280 УК РФ) Аля определения направленности содержания и авторства текстов.

Помимо традиџионных криминалистических экспертиз (Аактимоскопической, трасологической, автороведческой, техническо-криминалистической экспертизы документов и Ар.), в ходе расследования преступлений экстремистской направленности широкое распространение получияи психологомингвистическая и религиоведческая судебные экспертизы, к проведению и оџенке результатов которых возникает ряа серьезных вопросов.

С џелью установления направленности высказываний и содержания текстов, размешенных в Интернете, назначается комплексная психолого-лингвистическая судебная экспертиза, предметом которой является установление в содержании текста призывов к экстремистским действиям, характер воздейс- 
твия данного текста на адресата и определение психологического речевого портрета автора текста [4] .

Исследуемым объектом в Аанном случае является вербальная информаџия, зафиксированная в интернет-коммуникации. Именно вербальная информация содержкит в себе специфические мингвистические признаки, на основании которых эксперт может охарактеризовать коммуникативную ситуацию, определить стратегию речевого поведения участников общения, выявить в интернет-сообщении признаки пропаганды экстремизма как системы взглядов и мировоззрения.

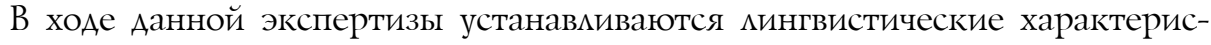
тики текста, на основе которых определяются психологические особенности коммуникативного поведения автора и особые приемы его манипуляторного воздействия на аудиторию. Психолого- ингвистическая экспертиза также позволяет выявить цингвистические признаки пропаганды, агитаџии или призывов к совершению противоправных действий и составить психологический речевой портрет автора исследуемого текста. Такой портрет может быть как индивидуацьным, так и комлективным, поскольку он, как правило, отражает особенности речи определенной общественно-соџиальной группы, а именно экстремистской группировки.

Проблемы, возникающие при оџенке качества полученных заключений,

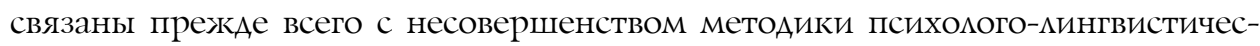
кой экспертизы. Это касается и комплекса методов, применяемых Аля исследования текстов, размещенных в Интернете, и формулировок вопросов, выносимых на разрешение экспертов. Аостаточно часто на разрешение экспертов при производстве Аанного вида экспертизы ставятся вопросы относительно объема и содержания таких уголовно-правовых понятий, как «призыв» и «экстремистская деятельность», поскольку эти противоправные деяния запрешены всеми нормами материального права. В уголовном законе Аанные Аействия расџениваются как преступиения экстремистской направленности, а совершение преступлений по мотивам политической, идеологической, расовой, национацьной или религиозной ненависти или вражаы мибо по мотивам ненависти ими вражды в отношении какой- ибо соџиамьной группы считается отягчающими обстоятельствами в соответствии с пунктом «е» ч. 1 ст. 63 УК РФ [2]. Установцение мотива преступления экстремистской направленности является искцючительной прерогативой слеАствия и суда. Психолого- ингвистическое исследование текстов, размещенных в Интернете, устанавцивает направленность содержания текста, которая косвенно связана с мотивом противоправного действия.

Еще одним проблемным аспектом при оџенке заключений психолого- иингвистической экспертизы явмяется установцение прямого умысла. Решение этой задачи напрямую связано с определением направценности действий автора текста. Преступления экстремистской направленности всегда совершаются с прямым умыслом, то есть автор осознает характер своих Аействий, понимает их публичность, предвидит и желает наступления определенных последствий. Иными словами, установление прямого умысла в действиях миџа, размещаю- 
щего информацию экстремистского содержания в Интернете, также явмяется правовым вопросом и решается в ходе предварительного следствия и судебного рассмотрения уголовного дела, но не в рамках психолого-лингвистической экспертизы.

Расследование преступлений экстремистской направленности осложняется еще и тем, что через Интернет осуществцяется связь и практически ничем не ограниченное взаимодействие чменов экстремистских организаций, финансируемых из-за рубежа. Речь идет о религиозных организаџиях с управленческим џентром за рубежом, деятельность которых имеет экстремистскую направленность, но которые, как правимо, прикрываются правомерными видами Аеятельности, например, соџиальной, образовательной, общественной, политической и т.п. Такая деятельность структурирована, тщательно спланирована, цеменаправленна и деструктивна по своей сути. В качестве примера можно привести формирование террористических организаций Ажихадистского толка и экстремистских неопротестантских организаций. Так, преступная деятельность так называемого, запрещенного в России «Искамского государства» распространена практически по всему миру, пропаганда терроризма и пополнение рядов осуществцяется чиенами Аанной организации как при их непосредственном присутствии в конкретных странах, так и посредством информационно-телекоммуникационных сетей.

Аалее следует отметить ряд проблем, которые возникают при назначении и производстве судебной религиовеАческой экспертизы экстремистских материалов и влекут за собой сложности при оџенке заключений экспертов и использования результатов экспертизы дия целей доказывания по уголовным декам, связанным с экстремизмом.

Производство и назначение религиоведческой экспертизы регулируется п. 8 ст. 11 Федерального закона «О свободе совести и религиозных объеАинениях [5], а порядок ее проведения в Экспертном совете при Министерстве юстищии РФ утвержАается приказом Министерства юстищии «О государственной религиоведческой экспертизе» от 18 февраля 2009 г. № 53 [6] .

Судебная религиоведческая экспертиза, назначаемая при расследовании преступцений экстремистской направленности, явмяется важным источником доказательств и позволяет определить характер исследуемого религиозного направления; установить конфессиональную принадеежность организаџии, распространяюшей экстремистские материалы; решить вопрос о мотиве преступления, совершенного на религиозной почве или Аиџом, относящимся к какой-мибо религиозной организации.

Наиболее часто судебная религиоведческая экспертиза назначается по децам о преступцениях экстремистской направленности, предусмотренных ст. 282 УК РФ «Возбуждение ненависти мибо вражды, а равно унижение человеческого достоинства», ст. 148 УК РФ «Нарушение права на свободу совести и вероисповеданий». Большое количество религиоведческих экспертиз в настоящее время назначается также дмя решения идентификаџионных задач, 


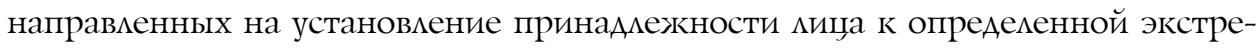
мистской организации.

В качестве исследуемых объектов на судебную религиоведческую экспертизу предоставцяются религиозная митература, распространяемая в Интернете; материалы, имлюстрирующие вероучение (изображкения предметов культа, символика религиозных организаций и пр.); Аокументы религиозного содержкания (учредительные Аокументы организации, религиозные образовательные программы и ар.); предметы религиозного назначения и Аругое.

Экспертный совет при Минюсте не является государственным экспертным учреждением, а входящие в него эксперты (как правицо, это священнослужители, психиатры, историки и философы) не имеют правового статуса эксперта, и их квалификация ничем не подтверждается. В связи с этим проведение религиоведческой экспертизы влечет за собой ряд правовых вопросов, уже обсуждавшихся в науке, и приводит к определенным сложностям при оџенке обоснованности выводов по результатам проведенной экспертизы [7].

Проблемы использования результатов религиоведческой экспертизы прежАе всего связаны с отсутствием законодательного закрепления еАиного понятия религиоведческой экспертизы и требований к компетенции экспертов в данной области. Отсутствуют также научно обоснованные методические разработки, позволяющие проводить религиоведческое исследование и однозначно решать криминалистические задачи расследования преступлений экстремистской направленности.

Более того, в настоящее время в России не существует каких-либо специализированных образовательных учреждений, готовящих спеџиалистов в Аанной отрасли знания, а также ни одного квалифицирующего органа, аттестующего экспертов-религиоведов. Аругими словами, правовой статус эксперта-религиоведа и его профессиональная компетенџия законодательно не закреплены, что препятствует эффективному использованию результатов рецигиоведческих экспертиз Аля целей доказывания по уголовным делам, связанным с экстремизмом.

Перечисленные проблемы требуют скорейшего решения в современных усмовиях, поскольку в Российском многонациональном государстве с разнообразием культур и конфессий неминуемо возникают экстремистские настроения, а религиоведческая экспертиза явцяется важнейшим источником доказательственной информации при расслеАовании религиозного экстремизма - одного из наиболее опасных преступлений экстремистской направленности.

На основании изложенного можно сделать вывод о том, что Аля получения наиболее качественных результатов исследования объектов религиоведческой экспертизы необходимо создать специализированное государственное экспертное учреждение, а проведение исследования поручать экспертам, прошеАшим соответствующую подготовку и имеющим кицензию на право провеАения религиоведческой экспертизы. С.И. Иванченко совершенно прав по поводу того, что в цемях успешного провеАения религиовеАческой экспертизы экспертом не Аолжен выступать священнослужитель или представитель какой бы то ни бымо конфессии [8]. 
Таким образом, в связи с распространением экстремистских идей в России возникает острая необходимость разработки оптимальной комплексной концепции противодействия экстремизму и внеАрения полученных результатов в Аеятельность правоохранительных органов.

Несмотря на предпринимаемые правоохранительными органами усилия по противодействию экстремизму, количество преступлений экстремистской направленности неуклонно растет, а в ходе их расследования возникает ряд сложностей, связанных со следующим:

- установлением на стадии возбуждения уголовного дела признаков преступцений экстремистской направленности по разжиганию наџиональной ненависти или вражды;

- использованием специальных знаний по киберпсихологии, психолингвистике и религиоведению в ходе расследования указанных преступлений;

- отграничением преступмений экстремистской направленности от общеуголовных преступмений;

- принятием неотложных мер по выявлению и пресечению таких преступцений в ходе проведения оперативно-розыскной деятемьности органами Аознания.

В связи с этим считаем, что Амя успешного расследования преступмений экстремистской направленности необходимо оптимизировать криминалистическую методику в части использования результатов оперативно-розыскной деятельности на стадии возбуждения уголовных дел и внести ряд поправок в действующее законодательство, регламентирующее применение специальных знаний для целей розыска и доказывания по уголовным делам, связанным с экстремизмом.

\section{Библиографический список}

1. О мерах по противодействию экстремистской деятельности: приказ Следственного комитета РФ от 12 июля 2011 г. № 109. URL: ttps://legalacts.ru/doc/prikaz-sledstvennogo-komitetarf-ot-12072011-n/

2. Уголовный кодекс Российской Федерации от 13 июня 1996 г. № 63-Ф3 (в ред. от 2 дек. 2019 г.) [Электронный ресурс]. Доступ из СПС «КонсультантПлюс».

3. Войскунский A.Е. Перспективы становления психологии Интернета // Психологический журнал. 2013. Т. 34, № 3. С. 110-118.

4. Желтухина М.Р., Кисляков В.П. О проблеме исследования продуктов речевой деятельности в рамках психолингвистической судебной экспертизы // Теория и практика судебной экспертизы. 2008. № 4. С. 219-223.

5. О свободе совести и религиозных объединениях: Федер. закон от 26 сент.1997 г. № 125-Ф3 (посл. ред.) [Электронный ресурс]. Доступ из СПС «КонсультантПлюс».

6. О государственной религиоведческой экспертизе: приказ Министерства юстиции от 18 февр. 2009 г. № 53 [Электронный ресурс]. Доступ из СПС «Гарант».

7. Вершицкая Г.В. Правовые особенности осуществления негосударственной экспертной деятельности // Вестник Поволжской академии государственной службы. 2014. № 2. C. 41-45.

8. Иванченко С.И. Проблемы обоснованности и достоверности выводов религиоведческой экспертизы // Исламоведение. 2013. № 4. С. 46-55. 